\title{
Analisis Bifurkasi Hopf Dan Kestabilan Model Dinamik Transmisi Virus Dengue Dengan Waktu Tunda Dalam Pengaruhnya Terhadap Kemunculan Penyakit Demam Berdarah Dengue
}

\author{
Chriestie E. J. C. Montolalu ${ }^{1 *}$, Charles E. Mongi ${ }^{2}$ \\ ${ }^{1,2}$ Program Studi Matematika, Fakultas Matematika dan Ilmu Pengetahuan Alam, \\ Universitas Sam Ratulangi Manado \\ *corresponding author email: chriestelly@yahoo.com
}

\begin{abstract}
Abstrak
Virus Dengue dapat diklasifikasikan pada empat serotipe virus, yaitu DEN-1, DEN-2, DEN-3, dan DEN-4. Jika salah satu dari keempat serotipe virus tersebut menginfeksi manusia, maka serotipe virus tersebut akan menetap dalam tubuh manusia yang diinfeksinya, dan manusia yang terinfeksi akan menjadi imun terhadap jenis serotipe virus tersebut. Jika di kemudian hari, manusia yang telah imun tersebut terinfeksi lagi dengan jenis serotipe virus yang berbeda, maka manusia tersebut akan terpapar penyakit Demam Berdarah Dengue (DBD). Model Matematika telah dirancang dalam bentuk sistem dengan empat asumsi yang didasarkan pada teori-teori dan hasil penelitian yang didapatkan pada literatur sumber. Keempat asumsi tersebut didasarkan pada waktu tunda $(\tau)$ sebagai parameter yang diamati pada penelitian ini. Selanjutnya, telah dilakukan analisa kestabilan masing-masing sistem terhadap titik kesetimbangan sistem. Hasil analisa menunjukkan bahwa parameter waktu tunda tidak mempengaruhi terhadap kestabilan sistem. Dengan demikian teori Bifurkasi Hopf tidak dapat dilakukan karena tidak adanya perubahan kestabilan sistem akibat perubahan parameter waktu tunda.
\end{abstract}

Kata kunci: Model Dinamik, Waktu Tunda, Sistem Persamaan Differensial, Bifurkasi Hopf.

\section{Hopf Bifurcation Analysis And Dengue Virus Transmission Dynamical Model Analysis With Delay Time In Its Influence To Dengue Hemorrhagic Fever Incident}

\begin{abstract}
Dengue Virus can be classified into four serotypes, i.e. DEN-1, DEN-2, DEN-3, and DEN-4. If one of the serotypes infects human, then it will stay in the body of the infected human, and he will develop immunity toward that kind of serotype. If in the future, the immune body get infected again by different kind of serotype virus, then the human will be exposed to Dengue Hemorrhagic Fever (DHF). A mathematical model has been conducted in a system which using four assumptions based on theories and research on references used in this paper. The four assumptions were based on delay time $(\tau)$ as parameter observed on this research. Moreover, stability of each system has been analyzed on equilibrium points. Results show that the delay time parameter do not affect the stability. Therefore, Hopf bifurcation theory could not be completed since there were no stability changing caused by delay time changing.
\end{abstract}

Keywords: Dynamical Model, Delay Time, Differential Equation System, Hopf Bifurcation.

\section{Pendahuluan}

Demam Dengue (DD) dan Demam Berdarah Dengue (DBD) disebabkan oleh virus Dengue yang teridentifikasi dalam empat jenis serotipe virus: DEN-1, DEN-2, DEN-3, dan DEN-4 [1]. Serotipe yang paling sering ditemukan di negara-negara tropis, termasuk Indonesia, adalah virus DEN-2 dan DEN-3 [2]. Walaupun penyakit DD dan DBD keduanya disebabkan oleh infeksi virus yang sama, tapi penyakit DD tidak sama dengan DBD. Penyakit DD muncul dalam tubuh manusia saat terinfeksi salah satu jenis serotipe virus dengue untuk pertama kalinya. Selanjutnya, manusia yang telah terinfeksi pertama kali tersebut akan imun seumur hidupnya terhadap virus yang telah menginfeksinya. Namun, jika kemudian manusia tersebut terinfeksi jenis serotipe virus lain yang 
berbeda dari jenis serotipe virus yang menginfeksi pertama kali, maka manusia tersebut akan sangat rentan terhadap penyakit DBD [1]. Dengan kata lain, penyakit DBD adalah fase yang lebih parah dari penyakit DD. Meskipun demikian, studi menunjukkan bahwa penyakit DBD yang muncul setelah infeksi kedua dari virus jenis serotipe yang berbeda tidak selamanya berakhir buruk. Walaupun ada yang bisa berakhir pada kematian, namun ada juga manusia yang bisa sembuh, atau bahkan tidak terlalu parah. Semuanya ini disebabkan oleh adanya perbedaan imunitas manusia yang berbeda-beda yang dipengaruhi oleh beberapa faktor, di antaranya adalah jenis kelamin, usia, dan asupan gizi [3]. Faktor-faktor ini menyebabkan adanya perbedaan masa inkubasi virus yang bisa menentukan parah atau tidaknya penyakit DBD yang dialami setelah infeksi kedua.

Studi matematis tentang DBD sendiri telah banyak dilakukan baik oleh para peneliti di Indonesia maupun di luar negeri dan telah mengalami banyak perkembangan. Di antaranya adalah dengan analisa terhadap model dinamik SIR dengan melibatkan lima kompartemen [4,5], yaitu: populasi manusia yang rentan terhadap virus atau succeptible $\left(S_{h}\right)$, populasi manusia yang terinfeksi virus atau infected $\left(I_{h}\right)$, populasi manusia yang telah melewati tahap penyembuhan atau removed $\left(R_{h}\right)$, populasi nyamuk yang rentan terhadap virus atau succeptible mosquitoes $\left(S_{v}\right)$, dan nyamuk yang terinfeksi virus atau infected mosquitoes $\left(I_{v}\right)$. Model ini dianalisis dengan mengasumsikan manusia sebagai host (pejamu) dan nyamuk sebagai vector. Model ini merupakan modifikasi dari model dinamik SIR yang diperkenalkan pada tahun 1927 oleh Kermack dan McKendrik [6]. Penyebaran virus dan perkembangan penyakit dianalisis melalui kestabilan model. Dalam hal ini, kestabilan model SIR ditentukan pada titik kesetimbangan semua variabel yang disimbolkan pada setiap kompartemen. Jika titik kesetimbangan menunjukkan perilaku stabil, maka penyakit diasumsikan tidak berkembang atau manusia ada pada fase penyembuhan. Sebaliknya jika titik kesetimbangan menunjukkan perilaku tidak stabil, maka penyakit diasumsikan pada fase yang parah dan bisa menyebabkan kematian. Oleh karena itu, model ini dapat membantu para penentu keputusan dalam bidang kesehatan dalam upaya mengontrol penyebaran penyakit karena dapat memberikan gambaran kondisi sistem pada saat penyebaran penyakit bisa fatal atau sebaliknya hilang dari sistem.

\section{Penyakit Demam Dengue (DD) dan Demam Berdarah Dengue (DBD)}

Penyakit Demam Berdarah Dengue (DBD) adalah fase yang lebih parah dari penyakit Demam Dengue (DD) [1]. Manusia yang terinfeksi salah satu dari keempat jenis serotipe virus dengue: DEN-1, DEN-2, DEN-3, dan DEN-4, akan menderita penyakit DD. Selanjutnya, setelah sembuh, virus tersebut akan menetap dalam tubuh manusia yang diinfeksinya dan manusia yang terinfeksi akan menjadi imun terhadap virus tersebut. Jika kemudian, manusia tersebut terinfeksi jenis serotipe virus lainnya, maka manusia tersebut akan terpapar penyakit DBD dikarenakan sistem imun tubuh telah dibentuk untuk serotipe virus yang telah menginfeksinya terlebih dahulu [1]. Penyakit DD bisa disembuhkan, sedangkan penyakit DBD walaupun masih bisa disembuhkan tapi bisa menyebabkan kematian.

\section{Model Matematika}

Pada tahun 2007, Nuraini et al. [7] mengembangkan model SIR dengan menambahkan kompartemen dua jenis serotipe virus dengue dan populasi manusia yang menderita penyakit DBD. Dua jenis serotipe virus dengue yang dilibatkan dalam sistem adalah virus dengue serotipe DEN-2 dan DEN-3 dengan mengacu pada temuan bahwa kedua jenis serotipe virus ini yang sering ditemukan pada negara-negara tropis seperti Indonesia [3]. Yang membedakan model ini dengan model SIR lainnya, termasuk model pada sistem (2), adalah adanya kompartemen populasi host yang menderita penyakit DBD setelah terinfeksi kedua kalinya oleh jenis serotipe virus dengue yang berbeda dari jenis serotipe virus yang menginfeksi host tersebut sebelumnya. Model in lebih spesifik menggambarkan detil perkembangan penyakit dari fase DD menuju DBD, bahkan pada kasus yang lebih parah. Model ini dinyatakan dalam sistem persamaan differensial 1a dan $1 \mathrm{~b}$.

$$
\begin{aligned}
& \frac{d \tilde{S}}{d t}=\mu_{h} N_{h}-\left(B_{1} V_{1}+B_{2} V_{2}\right) \tilde{S}-\mu_{h} \tilde{S}, \\
& \frac{d \tilde{I}_{1}}{d t}=B_{1} V_{1} \tilde{S}-\left(\gamma+\mu_{h}\right) \tilde{I}_{1} \\
& \frac{d \tilde{I}_{2}}{d t}=B_{2} V_{2} \tilde{S}-\left(\gamma+\mu_{h}\right) \tilde{I}_{2}
\end{aligned}
$$




$$
\begin{aligned}
& \frac{d \tilde{R}_{1}}{d t}=\gamma \tilde{I}_{1}-\sigma_{2} B_{2} V_{2} \tilde{R}_{1}-\mu_{h} \tilde{R}_{1}, \\
& \frac{d \tilde{R}_{2}}{d t}=\gamma \tilde{I}_{2}-\sigma_{1} B_{1} V_{1} \tilde{R}_{2}-\mu_{h} \tilde{R}_{2}, \\
& \frac{d \tilde{D}}{d t}=q\left(\sigma_{2} B_{2} V_{2} \tilde{R}_{1}+\sigma_{1} B_{1} V_{1} \tilde{R}_{2}\right)-\left(\mu_{h}+\gamma\right) \widetilde{D}, \\
& \frac{d \tilde{Y}_{1}}{d t}=(1-q) \sigma_{1} B_{1} V_{1} \tilde{R}_{2}-\left(\gamma+\mu_{h}\right) \tilde{Y}_{1}, \\
& \frac{d \tilde{Y}_{2}}{d t}=(1-q) \sigma_{2} B_{2} V_{2} \tilde{R}_{1}-\left(\gamma+\mu_{h}\right) \tilde{Y}_{2}, \\
& \frac{d \tilde{R}}{d t}=\gamma\left(\tilde{Y}_{1}+\tilde{Y}_{2}\right)-\mu_{h} \tilde{R}+\gamma \widetilde{D}, \\
& \text { dengan populasi vector } \\
& \frac{d V_{0}(t)}{d t}=\mu_{v}-\left[A_{1}\left(\frac{\tilde{I}_{1}}{N_{h}}+\frac{\tilde{Y}_{1}}{N_{h}}\right)+A_{2}\left(\frac{\tilde{I}_{2}}{N_{h}}+\frac{\tilde{Y}_{2}}{N_{h}}\right)\right]-\mu_{v} V_{0}, \\
& \frac{d V_{1}(t)}{d t}=A_{1}\left(\frac{\tilde{I}_{1}}{N_{h}}+\frac{\tilde{Y}_{1}}{N_{h}}\right) V_{0}-\mu_{v} V_{1}, \\
& \frac{d V_{2}(t)}{d t}=A_{2}\left(\frac{\tilde{I}_{2}}{N_{h}}+\frac{\tilde{Y}_{2}}{N_{h}}\right) V_{0}-\mu_{v} V_{2} .
\end{aligned}
$$

dengan pernyataan-pernyataan:

Misalkan $N_{h}$ menyatakan populasi manusia sebagai host, $N_{v}$ menyatakan populasi nyamuk sebagai vector, $i$ dan $j$ menyatakan serotipe kedua virus, dengan variabel-variabel:

$S$ untuk menyatakan populasi manusia yang rentan terhadap kedua jenis serotipe virus dengue

$I_{i}$ untuk menyatakan populasi manusia yang terinfeksi jenis serotipe virus $i$

$R_{i}$ untuk menyatakan populasi manusia yang imun terhadap jenis serotipe virus $i$

$Y_{i}$ untuk menyatakan populasi manusia yang imun terhadap jenis serotipe virus $j$ dan terinfeksi jenis serotipe virus $i$

$R$ untuk menyatakan populasi manusia yang imun terhadap kedua jenis serotipe virus

$D$ untuk menyatakan populasi manusia yang imun terhadap jenis serotipe 1 atau 2 dan telah terinfeksi jenis serotipe virus berbeda dan menderita penyakit DBD.

$V_{0}$ untuk menyatakan proporsi vector nyamuk yang rentan

$V_{i}$ untuk menyatakan proporsi vector nyamuk yang terinfeksi virus $i$.

Model ini diasumsikan sebagai berikut:

Perkembangan penyakit dimulai pada $S$ kemudian menuju $I_{1}$ dan $I_{2}$. Selanjutnya dari $I_{1}$ ke $R_{1}$ dan dari $I_{2}$ ke $R_{2}$. Diasumsikan bahwa proporsi $q$ manusia pada $R_{i}$ berkembang menjadi penderita penyakit DBD dan berpindah pada kompartemen $D$, sedangkan proporsi $1-q$ manusia berpindah pada kompertemen $Y_{i}$. Dalam model ini diasumsikan bahwa tidak ada transmisi virus dari kompartemen $D$ ke vector, hanya dari kompartemen $I$ dan $Y$ dan tidak ada angka kematian pada kompartemenkompartemen ini karena populasi manusia pada kompartemen-kompartemen ini diasumsikan telah ditangani secara medis dan dihindarkan dari vector nyamuk. Tujuan dari analisa model ini adalah untuk mengurangi populasi manusia yang berkembang pada fase penyakit DBD atau setidaknya berada pada level yang wajar.

Analisis terhadap model ini menunjukkan adanya empat titik kesetimbangan. Dengan adanya angka reproduksi serotipe virus $T_{i}, \forall i \in\{1,2\}$, dimana $T_{1}$ menyatakan angka reproduksi virus serotipe 1 dan $T_{2}$ menyatakan angka reproduksi virus serotipe 2.

Titik kesetimbangan pertama menunjukkan perilaku asimtotik stabil jika $T_{i}<1$.

Titik kesetimbangan kedua dan ketiga menunjukkan perilaku asimtotik stabil jika salah satu serotipe virus $T_{i}>1$ dan serotipe virus lainnya $T_{j}<\frac{T_{i}}{1+\frac{\gamma \sigma_{j} B_{i}(1-q)\left(T_{i}-1\right)}{\left(\mu_{h} T_{i}+B_{i}\right)\left(\mu_{h}+\gamma\right)^{2}}}, i, j=1,2, i \neq j$.

Titik kesetimbangan keempat menunjukkan perilaku asimtotik stabil jika

$$
1<T<\frac{B\left(B \sigma \mu_{v}+2 A \mu_{h}^{2}+\Lambda(2+\sigma)\right)}{2 \mu_{h} \Lambda}, \Lambda=\mu_{h} \mu_{v}\left(\mu_{h}+\gamma\right) \text {. }
$$

Titik kesetimbangan yang menunjukkan perilaku stabil mengindikasikan bahwa penyakit DBD tidak berkembang atau menghilang dari sistem. 


\section{Waktu Tunda (Time Delay) dan Bifurkasi Hopf (Hopf Bifurcation)}

Studi dalam penyakit menular menunjukkan bahwa adanya perbedaan imunitas manusia sering menyebabkan terjadi variasi pada masa inkubasi virus yang terinfeksi pada tubuhnya. Faktor-faktor seperti usia, gizi, dan jenis kelamin menyebabkan perbedaan imunitas [3]. Pada akhirnya, masa inkubasi virus dalam tubuh manusia yang terinfeksi bisa mengalami keterlambatan dari masa inkubasi yang sebenarnya. Demikian juga, jika manusia tersebut melakukan pencegahan terhadap penyakit dengan melakukan vaksinasi. Studi menunjukkan bahwa vaksinasi bisa menyebabkan terjadinya penundaan inkubasi virus dalam tubuh manusia terinfeksi [8].

Secara matematis penundaan pada masa inkubasi tersebut sering disebutkan sebagai waktu tunda (time delay). Terutama dalam model dinamik, waktu tunda dapat mempengaruhi kestabilan sistem. Waktu tunda bisa menyebabkan perubahan kestabilan pada titik kesetimbangan sistem, titik yang sebenarnya stabil tapi kemudian mengalami waktu tunda bisa berubah menjadi tidak stabil, demikian sebaliknya titik yang sebelumnya tidak stabil bisa berubah menjadi stabil $[8,9,10]$. Efek waktu tunda pada model SIR, khususnya untuk penyakit DD, menunjukkan perubahan kestabilan transmisi virus dan perkembangan penyakit [11].

Perubahan kestablian sistem bisa dianalisis dengan melihat terjadinya Bifurkasi Hopf pada titik kesetimbangan sistem. Bifurkasi Hopf (Hopf bifurcation) akan terjadi pada sistem persamaan differensial jika terjadi perubahan struktur orbit pada titik kestimbangannya akibat adanya perubahan parameter [12]. Model SIR dengan waktu tunda telah banyak dianalisis dengan bifurkasi Hopf untuk melihat perubahan kestabilannya $[11,13,14]$.

Ada beberapa tahapan untuk menguji kestabilan model SIR dengan waktu tunda dengan melihat terjadinya bifurkasi Hopf pada sistem tersebut, seperti yang dilakukan oleh Kumar et. Al. [14]. Model yang akan dianalisis diasumsikan melibatkan waktu tunda, misalnya jika ingin melihat pengaruh waktu tunda pada populasi manusia yang rentan, $S$, maka fungsi $S(t)$ terhadap waktu terhadap waktu $t$ akan menjadi $S(t-\tau)$ dengan $\tau$ merupakan parameter waktu tunda. Selanjutnya, kesetimbangan semua variabel dalam sistem diperiksa dengan menentukan titik kesetimbangan. Titik kesetimbangan sistem ditentukan dengan membuat setiap persamaan differensial pada sistem bernilai nol (misalnya $\frac{d \tilde{s}}{d t}=0$ ) dan diselesaikan dengan prinsip sistem persamaan linear. Kestabilan titik kesetimbangan kemudian dianalisa untuk variasi nilai $\tau$ yang otomatis tidak boleh negatif. Kestabilan titik kesetimbangan dianalisa pada nilai eigen yang muncul dari sistem. Kemudian jika kestablian berubah seiring dengan perubahan nilai $\tau$, maka akan terjadi bifukasi Hopf. Kemunculan bifurkasi akan menentukan jenis perubahan kestabilan titik kesetimbangan sistem berdasarkan jenis bifurkasi Hopf yang muncul. Jenis bifurkasi Hopf lebih spesifik dijelaskan pada teorema Bifurkasi Hopf.

Teorema Bifurkasi Hopf [12]

Misalkan sistem persamaan differensial

$\left.\dot{x}=f_{\mu}(x, y)\right)$

$\left.\dot{\mathrm{y}}=g_{\mu}(\mathrm{x}, \mathrm{y})\right\}$

dimana $\mu$ merupakan parameter. Misalkan sistem (2) mempunyai titik kesetimbangan $(x, y)=$ $\left(x_{0}, y_{0}\right)$ dan nilai eigen dari sistem (2) yang telah dilinearkan adalah $\lambda(\mu)$ dan $\bar{\lambda}(\mu)=\alpha(\mu) \pm i \beta(\mu)$. Selanjutnya, untuk sembarang nilai $\mu$, misalkan $\mu=\mu_{0}$, kondisi-kondisi berikut dipenuhi:

1. $\alpha\left(\mu_{0}\right)=0, \beta\left(\mu_{0}\right)=\omega \neq 0$ dimana $\operatorname{sgn}(\omega)=\operatorname{sgn}\left[\left.\left(\partial g_{\mu} / \partial x\right)\right|_{\mu=\mu_{0}}\left(x_{0}, y_{0}\right)\right]$

2. $\left.\frac{d \alpha(\mu)}{d \mu}\right|_{\mu=\mu_{0}}=d \neq 0$

3. $a \neq 0$, dimana

$$
\begin{aligned}
& a=\frac{1}{16}\left(f_{x x x}+f_{x y y}+g_{x x y}+g_{y y y}\right)+\frac{1}{16 \omega}\left(f_{x y}\left(f_{x x}+f_{y y}\right)-g_{x y}\left(g_{x x}+g_{y y}\right)-f_{x x} g_{x x}+\right. \\
& \left.\quad f_{y y} g_{y y}\right), \\
& \text { dengan } f_{x y}=\left.\left(\partial^{2} f_{\mu} / \partial x \partial y\right)\right|_{\mu=\mu_{0}}\left(x_{0}, y_{0}\right) \text {, dan seterusnya. }
\end{aligned}
$$

Kurva solusi periodik mengalami bifurkasi dari titik ekulibrium ke daerah $\mu>\mu_{0}$ jika ad $<0$ atau $\mu<\mu_{0}$ jika $a d>0$. Titik kesetimbangan merupakan titik yang stabil untuk $\mu>\mu_{0}$ dan tidak stabil untuk $\mu<\mu_{0}$ jika $d<0$, dan berlaku juga untuk sebaliknya. Solusi periodik pada saat $\mu=\mu_{0}$ 
bersifat stabil jika titik kesetimbangan bersifat tidak stabil, demikian juga sebaliknya. Bifurkasi disebut supercritical jika solusi periodik bifurkasi bersifat stabil dan disebut subcritical jika solusi periodik bersifat tidak stabil.

\section{Hasil dan Pembahasan}

\subsection{Formulasi Model}

Model yang digunakan dalam penelitian mengacu pada sistem 1 (1a dan 1b) yang telah dimodifikasi dengan menyederhanakan variabel-variabelnya untuk kemudahan proses analisis.

Misalkan $S=\frac{\tilde{S}}{N_{h}}, I_{1}=\frac{\widetilde{I_{1}}}{N_{h}}, I_{2}=\frac{\widetilde{I_{2}}}{N_{h}}, R_{1}=\frac{\widetilde{R_{1}}}{N_{h}}, R_{2}=\frac{\widetilde{R_{2}}}{N_{h}}, Y_{1}=\frac{\widetilde{Y_{1}}}{N_{h}}, Y_{2}=\frac{\widetilde{Y_{2}}}{N_{h}}, D=\frac{\widetilde{D}}{N_{h}}$

Sehingga didapatkan model sebagai berikut:

$\frac{d S}{d t}=(1-S) \mu_{h}-\left(B_{1} V_{1}+B_{2} V_{2}\right) S$,

$\frac{d I_{1}}{d t}=B_{1} V_{1} S-\left(\gamma+\mu_{h}\right) I_{1}$,

$\frac{d I_{2}}{d t}=B_{2} V_{2} S-\left(\gamma+\mu_{h}\right) I_{2}$,

$\frac{d R_{1}}{d t}=\gamma I_{1}-\sigma_{2} B_{2} V_{2} R_{1}-\mu_{h} R_{1}$

$\frac{d R_{2}}{d t}=\gamma I_{2}-\sigma_{1} B_{1} V_{1} R_{2}-\mu_{h} R_{2}$,

$\frac{d D}{d t}=q\left(\sigma_{2} B_{2} V_{2} R_{1}+\sigma_{1} B_{1} V_{1} R_{2}\right)-\left(\mu_{h}+\gamma\right) D$,

$\frac{d Y_{1}}{d t}=(1-q) \sigma_{1} B_{1} V_{1} R_{2}-\left(\gamma+\mu_{h}\right) Y_{1}$,

$\frac{d Y_{2}}{d t}=(1-q) \sigma_{2} B_{2} V_{2} R_{1}-\left(\gamma+\mu_{h}\right) Y_{2}$,

$\frac{d V_{1}}{d t}=A_{1}\left(I_{1}+Y_{1}\right)\left(1-V_{1}-V_{2}\right)-\mu_{v} V_{1}$,

$\frac{d V_{2}}{d t}=A_{2}\left(I_{2}+Y_{2}\right)\left(1-V_{1}-V_{2}\right)-\mu_{v} V_{2}$,

Berdasarkan asumsi bahwa pada proses penularan virus sering terjadi masa inkubasi yang bisa menyebabkan terjadinya waktu tunda seperti yang telah dijelaskan. Maka pada saat penularan penyakit yang diasumsikan dengan formula $B_{i} V_{i}(t) S(t)$, vektor $V_{i}(t)$ tidak hanya dipengaruhi oleh waktu $t$ saja namun juga oleh waktu tunda $\tau$. Waktu tunda ini diasumsikan bisa terjadi dalam empat kemungkinan:

1. Saat infeksi pertama oleh salah satu vektor saja,

2. Saat infeksi pertama oleh masing-masing vektor,

3. Saat infeksi kedua oleh vektor kedua

4. Saat infeksi pertama dan kedua oleh setiap vektor (pada semua masa inkubasi dalam sistem)

Dengan demikian sistem (3) dapat dianalisa dalam empat bentuk:

1. Dengan waktu tunda pada infeksi pertama oleh salah satu vektor:

$$
\begin{aligned}
& \frac{d S(t)}{d t}=(1-S(t)) \mu_{h}-\left(B_{i} V_{i}(t-\tau)+B_{j} V_{j}(t)\right) S(t), \\
& \frac{d I_{i}(t)}{d t}=B_{i} V_{i}(t-\tau) S(t)-\left(\gamma+\mu_{h}\right) I_{i}(t), \\
& \frac{d I_{j}(t)}{d t}=B_{2} V_{2}(t) S(t)-\left(\gamma+\mu_{h}\right) I_{2}(t), \\
& \frac{d R_{i}(t)}{d t}=\gamma I_{i}(t)-\sigma_{j} B_{j} V_{j}(t) R_{i}(t)-\mu_{h} R_{i}(t), \\
& \frac{d D(t)}{d t}=q\left(\sigma_{j} B_{j} V_{j}(t) R_{i}(t)+\sigma_{i} B_{i} V_{i}(t) R_{j}(t)\right)-\left(\mu_{h}+\gamma\right) D(t), \\
& \frac{d Y_{i}(t)}{d t}=(1-q) \sigma_{i} B_{i} V_{i}(t) R_{j}(t)-\left(\gamma+\mu_{h}\right) Y_{i}(t), \\
& \frac{d V_{i}(t)}{d t}=A_{i}\left(I_{i}(t)+Y_{i}(t)\right)\left(1-V_{i}(t)-V_{j}(t)\right)-\mu_{v} V_{i}(t),
\end{aligned}
$$

2. Dengan waktu tunda pada infeksi pertama oleh masing-masing vektor:

$$
\begin{aligned}
& \frac{d S(t)}{d t}=(1-S(t)) \mu_{h}-\left(B_{i} V_{i}(t-\tau)+B_{j} V_{j}(t-\tau)\right) S(t), \\
& \frac{d I_{i}(t)}{d t}=B_{i} V_{i}(t-\tau) S(t)-\left(\gamma+\mu_{h}\right) I_{i}(t), \\
& \frac{d I_{j}(t)}{d t}=B_{2} V_{2}(t-\tau) S(t)-\left(\gamma+\mu_{h}\right) I_{2}(t),
\end{aligned}
$$




$$
\begin{aligned}
& \frac{d R_{i}(t)}{d t}=\gamma I_{i}(t)-\sigma_{j} B_{j} V_{j}(t) R_{i}(t)-\mu_{h} R_{i}(t), \\
& \frac{d D(t)}{d t}=q\left(\sigma_{j} B_{j} V_{j}(t) R_{i}(t)+\sigma_{i} B_{i} V_{i}(t) R_{j}(t)\right)-\left(\mu_{h}+\gamma\right) D(t), \\
& \frac{d Y_{i}(t)}{d t}=(1-q) \sigma_{i} B_{i} V_{i}(t) R_{j}(t)-\left(\gamma+\mu_{h}\right) Y_{i}(t), \\
& \frac{d V_{i}(t)}{d t}=A_{i}\left(I_{i}(t)+Y_{i}(t)\right)\left(1-V_{i}(t)-V_{j}(t)\right)-\mu_{v} V_{i}(t),
\end{aligned}
$$

3. Dengan waktu tunda pada infeksi kedua oleh vektor kedua

$$
\begin{aligned}
& \frac{d S(t)}{d t}=(1-S(t)) \mu_{h}-\left(B_{i} V_{i}(t)+B_{j} V_{j}(t)\right) S(t), \\
& \frac{d I_{i}(t)}{d t}=B_{i} V_{i}(t) S(t)-\left(\gamma+\mu_{h}\right) I_{i}(t), \\
& \frac{d I_{j}(t)}{d t}=B_{2} V_{2}(t) S(t)-\left(\gamma+\mu_{h}\right) I_{2}(t), \\
& \frac{d R_{i}(t)}{d t}=\gamma I_{i}(t)-\sigma_{j} B_{j} V_{j}(t-\tau) R_{i}(t)-\mu_{h} R_{i}(t), \\
& \frac{d D(t)}{d t}=q\left(\sigma_{j} B_{j} V_{j}(t-\tau) R_{i}(t)+\sigma_{i} B_{i} V_{i}(t-\tau) R_{j}(t)\right)-\left(\mu_{h}+\gamma\right) D(t), \\
& \frac{d Y_{i}(t)}{d t}=(1-q) \sigma_{i} B_{i} V_{i}(t) R_{j}(t)-\left(\gamma+\mu_{h}\right) Y_{i}(t), \\
& \frac{d V_{i}(t)}{d t}=A_{i}\left(I_{i}(t)+Y_{i}(t)\right)\left(1-V_{i}(t)-V_{j}(t)\right)-\mu_{v} V_{i}(t),
\end{aligned}
$$

4. Dengan waktu tunda pada semua masa inkubasi dalam sistem (infeksi pertama dan kedua oleh setiap vektor)

$$
\begin{aligned}
& \frac{d S(t)}{d t}=(1-S(t)) \mu_{h}-\left(B_{i} V_{i}(t-\tau)+B_{j} V_{j}(t-\tau)\right) S(t), \\
& \frac{d I_{i}(t)}{d t}=B_{i} V_{i}(t-\tau) S(t)-\left(\gamma+\mu_{h}\right) I_{i}(t), \\
& \frac{d I_{j}(t)}{d t}=B_{2} V_{2}(t-\tau) S(t)-\left(\gamma+\mu_{h}\right) I_{2}(t), \\
& \frac{d R_{i}(t)}{d t}=\gamma I_{i}(t)-\sigma_{j} B_{j} V_{j}(t-\tau) R_{i}(t)-\mu_{h} R_{i}(t), \\
& \frac{d D(t)}{d t}=q\left(\sigma_{j} B_{j} V_{j}(t-\tau) R_{i}(t)+\sigma_{i} B_{i} V_{i}(t-\tau) R_{j}(t)\right)-\left(\mu_{h}+\gamma\right) D(t), \\
& \frac{d Y_{i}(t)}{d t}=(1-q) \sigma_{i} B_{i} V_{i}(t) R_{j}(t)-\left(\gamma+\mu_{h}\right) Y_{i}(t), \\
& \frac{d V_{i}(t)}{d t}=A_{i}\left(I_{i}(t)+Y_{i}(t)\right)\left(1-V_{i}(t)-V_{j}(t)\right)-\mu_{v} V_{i}(t),
\end{aligned}
$$

\subsection{Titik Ekuilibrium}

Untuk menentukan kestabilan sistem maka diperlukan terlebih dahulu titik ekuilibrium dari sistem. Titik ekuilibrium sistem bisa ditentukan dengan membuat semua persamaan differensial pada sistem bernilai nol.

Dengan menetapkan $\frac{d S}{d t}=\frac{d I_{1}}{d t}=\frac{d I_{2}}{d t}=\frac{d R_{1}}{d t}=\frac{d R_{2}}{d t}=\frac{d D}{d t}=\frac{d Y_{1}}{d t}=\frac{d Y_{2}}{d t}=\frac{d V_{1}}{d t}=\frac{d V_{2}}{d t}=0, \quad$ maka didapatkan sebagai berikut:

i. Titik ekuilibrium bebas penyakit Jika $I_{1}=0$ atau $I_{2}=0$ atau keduanya bernilai nol, maka diperoleh titik ekuilibrium bebas penyakit:

ii. Titik ekuilibrium endemik

$$
E_{0}=(1,0,0,0,0,0,0,0,0,0)
$$

Jika $I_{1} \neq 0$ atau $I_{2} \neq 0$ atau keduanya tidak bernilai nol, maka diperoleh titik ekuilibrium endemik

$$
E_{1}=\left(S_{1}^{*}, I_{1}^{*}, I_{2}^{*}, R_{1}^{*}, R_{2}^{*}, D^{*}, Y_{1}^{*}, Y_{2}^{*}, V_{1}^{*}, V_{2}^{*}\right)
$$

\subsection{Kestabilan Titik Ekuilibrium}

Karena sistem (3) adalah sistem yang nonlinear yang mengakibatkan sistem (4) - (7) berbentuk nonlinear, maka untuk menentukan kestabilan titik ekuilibrium perlu dilakukan linearisasi sistem dengan menggunakan teori deret Taylor.

Variabel-variabel pada sistem bisa dimisalkan sebagai berikut: 
$x_{1}(t)=S(t)-S^{*}, x_{2}(t)=I_{1}(t)-I_{1}^{*}, x_{3}(t)=I_{2}(t)-I_{2}^{*}, x_{4}(t)=R_{1}(t)-R_{1}^{*}, x_{5}(t)=R_{2}(t)-$ $R_{2}^{*}, x_{6}(t)=D(t)-D^{*}, x_{7}(t)=Y_{1}(t)-Y_{1}^{*}, x_{8}(t)=Y_{2}(t)-Y_{2}^{*}, x_{9}(t)=V_{1}(t)-V_{1}^{*}, x_{10}(t)=$ $V_{2}(t)-V_{2}^{*}$

Dengan deret Taylor diperoleh

$$
\begin{aligned}
& \dot{x}_{1}(t)=-\left(\mu_{h}+B_{1} V_{1}^{*}+B_{2} V_{2}^{*}\right) x_{1}(t)-B_{1} S^{*} x_{9}(t)-B_{2} S^{*} x_{10}(t), \\
& \dot{x}_{2}(t)=B_{1} V_{1}^{*} x_{1}(t)-\left(\gamma+\mu_{h}\right) x_{2}(t)-B_{1} S^{*} x_{9}(t), \\
& \dot{x}_{3}(t)=B_{2} V_{2}^{*} x_{1}(t)-\left(\gamma+\mu_{h}\right) x_{3}(t)-B_{2} S^{*} x_{10}(t), \\
& \dot{x}_{4}(t)=\gamma x_{2}(t)-\left(\sigma_{2} B_{2} V_{2}^{*}+\mu_{h}\right) x_{4}(t)-\sigma_{2} B_{2} R_{1}^{*} x_{10}(t), \\
& \dot{x}_{5}(t)=\gamma x_{3}(t)-\left(\sigma_{1} B_{1} V_{1}^{*}+\mu_{h}\right) x_{5}(t)-\sigma_{1} B_{1} R_{2}^{*} x_{9}(t), \\
& \dot{x}_{6}(t)=q \sigma_{2} B_{2} V_{2}^{*} x_{4}(t)+q \sigma_{1} B_{1} V_{1}^{*} x_{5}(t)-\left(\mu_{h}+\gamma\right) x_{6}(t)+q \sigma_{1} B_{1} R_{2}^{*} x_{9}(t)+q \sigma_{2} B_{2} R_{1}^{*} x_{10}(t), \\
& \dot{x}_{7}(t)=(1-q) \sigma_{1} B_{1} V_{1}^{*} x_{5}(t)-\left(\gamma+\mu_{h}\right) x_{7}(t)+(1-q) \sigma_{1} B_{1} R_{2}^{*} x_{9}(t), \\
& \dot{x}_{8}(t)=(1-q) \sigma_{2} B_{2} V_{2}^{*} x_{4}(t)-\left(\gamma+\mu_{h}\right) x_{8}(t)+(1-q) \sigma_{2} B_{2} R_{1}^{*} x_{10}(t), \\
& \dot{x}_{9}(t)=A_{1}\left(1-V_{1}^{*}-V_{2}^{*}\right) x_{2}(t)+A_{1}\left(1-V_{1}^{*}-V_{2}^{*}\right) x_{7}(t)-\left(A_{1}\left(I_{1}^{*}+Y_{1}^{*}\right)+\mu_{v}\right) x_{9}(t) \\
& \quad-A_{1}\left(I_{1}^{*}+Y_{1}^{*}\right) x_{10}(t), \\
& \quad-\left(A_{2}\left(I_{1}^{*}+Y_{1}^{*}\right)+\mu_{v}\right) x_{10}(t),
\end{aligned}
$$

\begin{tabular}{|c|c|c|c|c|c|c|c|c|c|}
\hline$\left[-\mu_{h}-\left(B_{1} V_{1}^{*}+B_{2} V_{2}^{*}\right)\right.$ & 0 & 0 & 0 & 0 & 0 & 0 & 0 & $-B_{1} S^{*} e^{-\lambda \tau}$ & $-B_{2} S^{*}$ \\
\hline$B_{1} V_{1}^{*} e^{-\lambda \tau}$ & $-\left(\gamma+\mu_{h}\right)$ & 0 & 0 & 0 & 0 & 0 & 0 & $-B_{1} S^{*}$ & 0 \\
\hline$B_{2} V_{2}^{*}$ & 0 & $-\left(\gamma+\mu_{h}\right)$ & 0 & 0 & 0 & 0 & 0 & 0 & $-B_{2} S^{*}$ \\
\hline 0 & $\gamma$ & 0 & $-\left(\sigma_{2} B_{2} V_{2}^{*}+\mu_{h}\right)$ & 0 & 0 & 0 & 0 & 0 & $-\sigma_{2} B_{2}^{*} R_{1}^{*}$ \\
\hline 0 & 0 & $\gamma$ & 0 & $-\left(\sigma_{1} B_{1} V_{1}^{*}+\mu_{h}\right)$ & 0 & 0 & 0 & $-\sigma_{1} B_{1}^{*} R_{2}^{*}$ & 0 \\
\hline 0 & 0 & 0 & $q \sigma_{2} B_{2} V_{2}^{*}$ & $q \sigma_{1} B_{1} V_{1}^{*} R_{2}^{*}$ & $-\left(\mu_{h}+\gamma\right)$ & 0 & 0 & $q \sigma_{1} B_{1}^{*} R_{2}^{*}$ & $q \sigma_{2} B_{2}^{*} R_{1}^{*}$ \\
\hline 0 & 0 & 0 & 0 & $(1-q) \sigma_{1} B_{1}^{*} V_{1}^{*}$ & 0 & $-\left(\gamma+\mu_{h}\right)$ & 0 & $(1-q) \sigma_{1} B_{1}^{*} R_{2}^{*}$ & 0 \\
\hline 0 & 0 & 0 & $(1-q) \sigma_{2} B_{2} V_{2}^{*}$ & (t) $\quad 0$ & 0 & 0 & $-\left(\gamma+\mu_{h}\right)$ & 0 & $(1-q) \sigma_{2} B_{2}^{*} R_{1}^{*}$ \\
\hline 0 & $A_{1}\left(1-V_{1}^{*}-V_{2}^{*}\right)$ & 0 & 0 & 0 & 0 & $A_{1}\left(1-V_{1}^{*}-V_{2}^{*}\right)$ & 0 & $-A_{1}\left(I_{1}^{*}+Y_{1}^{*}\right)-\mu_{v}$ & $-A_{1}\left(I_{1}^{*}+Y_{1}^{*}\right)$ \\
\hline 0 & 0 & $A_{2}\left(1-V_{1}^{*}-V_{2}^{*}\right)$ & 0 & 0 & 0 & 0 & $A_{2}\left(1-V_{1}^{*}-V_{2}^{*}\right)$ & $-A_{2}\left(I_{2}^{*}+Y_{2}^{*}\right)$ & $-A_{2}\left(I_{2}^{*}+Y_{2}^{*}\right)-\mu_{v}$ \\
\hline
\end{tabular}

Misalkan solusi dari persamaan (4) adalah

$x_{1}(t)=a e^{\lambda t}, x_{2}(t)=b e^{\lambda t}, x_{3}(t)=c e^{\lambda t}, x_{4}(t)=d e^{\lambda t}, x_{5}(t)=f e^{\lambda t}, x_{6}(t)=g e^{\lambda t}, \quad x_{7}(t)=$ $h e^{\lambda t}, x_{8}(t)=i e^{\lambda t}, x_{9}(t)=j e^{\lambda t}, x_{10}(t)=k e^{\lambda t}$,

Maka analisis kestabilan model dapat dilakukan dengan menggunaakan empat asumsi yang telah dibahas sebagai berikut:

1. Dengan waktu tunda pada infeksi pertama oleh salah satu vektor:

$$
\begin{aligned}
& a \lambda=-\left(\mu_{h}+B_{1} V_{1}^{*}+B_{2} V_{2}^{*}\right) a-B_{1} S^{*} j e^{-\lambda \tau}-B_{2} S^{*} k, \\
& b \lambda=B_{1} V_{1}^{*} a e^{-\lambda \tau}-\left(\gamma+\mu_{h}\right) b-B_{1} S^{*} j, \\
& c \lambda=B_{2} V_{2}^{*} a-\left(\gamma+\mu_{h}\right) c-B_{2} S^{*} k, \\
& d \lambda=\gamma b-\left(\sigma_{2} B_{2} V_{2}^{*}+\mu_{h}\right) d-\sigma_{2} B_{2} R_{1}^{*} k, \\
& f \lambda=\gamma c-\left(\sigma_{1} B_{1} V_{1}^{*}+\mu_{h}\right) f-\sigma_{1} B_{1} R_{2}^{*} j, \\
& g \lambda=q \sigma_{2} B_{2} V_{2}^{*} d+q \sigma_{1} B_{1} V_{1}^{*} f-\left(\mu_{h}+\gamma\right) g+q \sigma_{1} B_{1} R_{2}^{*} j+q \sigma_{2} B_{2} R_{1}^{*} k, \\
& h \lambda=(1-q) \sigma_{1} B_{1} V_{1}^{*} f-\left(\gamma+\mu_{h}\right) h+(1-q) \sigma_{1} B_{1} R_{2}^{*} j, \\
& i \lambda=(1-q) \sigma_{2} B_{2} V_{2}^{*} d-\left(\gamma+\mu_{h}\right) i+(1-q) \sigma_{2} B_{2} R_{1}^{*} k, \\
& j \lambda=A_{1}\left(1-V_{1}^{*}-V_{2}^{*}\right) b+A_{1}\left(1-V_{1}^{*}-V_{2}^{*}\right) h-\left(A_{1}\left(I_{1}^{*}+Y_{1}^{*}\right)+\mu_{v}\right) j-A_{1}\left(I_{1}^{*}+Y_{1}^{*}\right) k, \\
& k \lambda=A_{2}\left(1-V_{1}^{*}-V_{2}^{*}\right) c+A_{2}\left(1-V_{1}^{*}-V_{2}^{*}\right) i-A_{2}\left(I_{1}^{*}+Y_{1}^{*}\right) j-\left(A_{2}\left(I_{1}^{*}+Y_{1}^{*}\right)+\mu_{v}\right) k,
\end{aligned}
$$

Selanjutnya kestabilan sistem dapat ditentukan melalui nilai eigen dari sistem tersebut. Untuk mencari nilai eigen maka harus dicari terlebih dahulu matrix Jacobian dari sistem:

Substitusikan masing-masing titik Ekuilbrium untuk menentukan kestabilan sistem di sekitar titik ekulibrium sebagai berikut:

- Untuk titik ekuilibrium $E_{0}=(1,0,0,0,0,0,0,0,0,0)$, matriks Jacobiannya adalah:

$\left[\begin{array}{cccccccccc}-\mu_{h} & 0 & 0 & 0 & 0 & 0 & 0 & 0 & -B_{1} e^{-\lambda \tau} & -B_{2} \\ 0 & -\left(\gamma+\mu_{h}\right) & 0 & 0 & 0 & 0 & 0 & 0 & -B_{1} & 0 \\ 0 & 0 & -\left(\gamma+\mu_{h}\right) & 0 & 0 & 0 & 0 & 0 & 0 & -B_{2} \\ 0 & \gamma & 0 & -\mu_{h} & 0 & 0 & 0 & 0 & 0 & 0 \\ 0 & 0 & \gamma & 0 & -\mu_{h} & 0 & 0 & 0 & 0 & 0 \\ 0 & 0 & 0 & 0 & 0 & -\left(\mu_{h}+\gamma\right) & 0 & 0 & 0 & 0 \\ 0 & 0 & 0 & 0 & 0 & 0 & -\left(\gamma+\mu_{h}\right) & 0 & 0 & 0 \\ 0 & 0 & 0 & 0 & 0 & 0 & 0 & -\left(\gamma+\mu_{h}\right) & 0 & 0 \\ 0 & A_{1} & 0 & 0 & 0 & 0 & A_{1} & 0 & -\mu_{v} & 0 \\ 0 & 0 & A_{2} & 0 & 0 & 0 & 0 & A_{2} & 0 & -\mu_{v}\end{array}\right]$


Dengan nilai eigen:

$\lambda_{1}=\lambda_{4}=\lambda_{5}=-\mu_{h}, \lambda_{2}=\lambda_{3}=\lambda_{6}=\lambda_{7}=\lambda_{8}=-\left(\gamma+\mu_{h}\right), \lambda_{9}=\lambda_{10}=-\mu_{v}$.

Karena nilai eigen semua bernilai negatif, maka dapat disimpulkan bahwa sistem bersifat stabil asimtotik pada titik ekuilibrium $E_{0}$. Kemudian, parameter waktu tunda tidak terdapat pada masing-masing nilai eigen, sehingga dapat disimpulkan bahwa waktu tunda tidak akan berpengaruh pada sistem di sekitar titik ekulibrium $E_{0}$. Kesimpulan ini berlaku untuk semua asumsi pada titik $E_{0}$ karena jika dilihat pada matriks Jacobian, titik $E_{0}$ akan menyebabkan matriks Jacobian pada setiap sistem yang diasumsikan bernilai sama. Untuk selanjutnya ketiga sistem lainnya yang telah diasumsikan hanya akan dianalisa pada titik ekuilibrium $E_{1}$.

- Untuk titik ekuilibrium $E_{1}=\left(S_{1}^{*}, I_{1}^{*}, I_{2}^{*}, R_{1}^{*}, R_{2}^{*}, D^{*}, Y_{1}^{*}, Y_{2}^{*}, V_{1}^{*}, V_{2}^{*}\right)$ didapat nilai eigen:

$\lambda_{1}=-\mu_{h}-\left(B_{1} V_{1}^{*}+B_{2} V_{2}^{*}\right)$,

$\lambda_{4}=-\left(\sigma_{2} B_{2} V_{2}^{*}+\mu_{h}\right)$,

$\lambda_{5}=-\left(\sigma_{1} B_{1} V_{1}^{*}+\mu_{h}\right)$,

$\lambda_{2}=\lambda_{3}=\lambda_{6}=\lambda_{7}=\lambda_{8}=-\left(\gamma+\mu_{h}\right)$,

$\lambda_{9}=-A_{1}\left(I_{1}^{*}+Y_{1}^{*}\right)-\mu_{v}$,

$\lambda_{10}=-A_{2}\left(I_{2}^{*}+Y_{2}^{*}\right)-\mu_{v}$

Karena semua parameter diasumsikan positif , maka semua nilai eigen untuk $E_{1}$ bernilai negatif atau sistem bersifat stabil asimtotik pada $E_{1}$. Selanjutnya, dikarenakan pada setiap nilai eigen tidak muncul parameter waktu tunda $(\tau)$, maka disimpulkan bahwa waktu tunda tidak berpengaruh pada sistem ini di sekitar titik $E_{1}$.

2. Dengan waktu tunda pada infeksi pertama oleh masing-masing vektor.

Dengan cara yang sama pada poin 1, didapat nilai eigen yang sama dengan nilai-nilai eigen pada sistem di poin 1, maka dapat disimpulkan bahwa sistem bersifat stabil asimtotik pada $E_{1}$ dan waktu tunda tidak berpengaruh pada sistem di sekitar titik $E_{1}$.

3. Dengan waktu tunda pada infeksi kedua oleh vektor kedua.

Dengan cara yang sama pada poin 1 dan 2, untuk titik ekuilibrium

$E_{1}=\left(S_{1}^{*}, I_{1}^{*}, I_{2}^{*}, R_{1}^{*}, R_{2}^{*}, D^{*}, Y_{1}^{*}, Y_{2}^{*}, V_{1}^{*}, V_{2}^{*}\right)$

didapat nilai-nilai eigen yang sama dengan nilai-nilai eigen pada sistem di poin $1 \& 2$, maka dapat disimpulkan bahwa sistem bersifat stabil asimtotik pada $E_{1}$ dan waktu tunda tidak berpengaruh pada sistem di sekitar titik $E_{1}$.

4. Dengan waktu tunda pada semua masa inkubasi dalam sistem (infeksi pertama dan kedua oleh setiap vektor)

Dengan cara yang sama pada poin 1,2 , dan 3 , untuk titik ekuilibrium $E_{1}=\left(S_{1}^{*}, I_{1}^{*}, I_{2}^{*}, R_{1}^{*}, R_{2}^{*}, D^{*}, Y_{1}^{*}, Y_{2}^{*}, V_{1}^{*}, V_{2}^{*}\right)$

didapat nilai-nilai eigen yang sama dengan nilai-nilai eigen pada sistem di poin 1,2, dan 3, maka dapat disimpulkan bahwa sistem bersifat stabil asimtotik pada $E_{1}$ dan waktu tunda tidak berpengaruh pada sistem di sekitar titik $E_{1}$.

\subsection{Bifurkasi Hopf}

Bifurkasi Hopf terjadi jika suatu sistem dinamik mengalami perubahan kestabilan akibat adanya perubahan satu atau lebih parameter. Dalam penelitian ini, seperti yang telah dijelaskan sebelumnya, tidak terjadi perubahan kestabilan akibat adanya parameter waktu tunda. Dengan kata lain, seberapa besarpun perubahan waktu tunda tidak akan mempengaruhi kestabilan sistem dari model yang digunakan dalam penelitian ini. Dengan demikian tidak terjadi bifurkasi dalam model ini dan analisis menggunakan teori Bifurkasi Hopf tidak bisa dilakukan.

\section{Kesimpulan dan Saran}

\subsection{Kesimpulan}

Parameter waktu tunda $(\tau)$ tidak mempengaruhi kestabilan sistem, sistem akan tetap stabil pada saat populasi dalam keadaan seimbang (baik pada saat $E_{0}$ maupun pada saat $E_{1}$ ). Dengan kata lain, meskipun waktu tunda diasumsikan terjadi pada masa inkubasi, penyakit tidak akan muncul dan 
menyebar pada saat proporsi populasi berada pada titik $E_{0}$ dan penyakit akan tetap muncul dan menyebar pada saat proporsi populasi berada pada titik $E_{1}$.

Tidak terjadi bifurkasi pada model sistem dinamik yang digunakan dalam penelitian ini walaupun diperkirakan masa inkubasi akan berubah seiring dengan perubahan waktu tunda. Sehingga tidak diperlukan analisis bifurkasi Hopf untuk model dalam penelitian ini.

\subsection{Saran}

Pada saat-saat tertentu, parameter waktu tunda pasti dapat berpengaruh secara signifikan dalam keseimbangan sistem. Oleh karena itu parameter ini masih sangat relevan untuk digunakan dalam analisis model dengan sistem berbeda.

\section{Ucapan Terimakasih}

Penulis mengucapkan terima kasih kepada Direktorat Riset dan Pengabdian pada Masyarakat (DRPM), Kementerian Riset Teknologi dan Pendidikan Tinggi Dirjen melalui Lembaga Penelitian dan Pengabdian kepada Masyarakat (LPPM) UNSRAT yang telah mendanai penelitian ini pada skim Penelitian Dosen Pemula (PDP) tahun 2017.

\section{Daftar Pustaka}

[1] Satari, H.I. dan M. Meiliasari, 2008. Demam Berdarah: Perawatan di Rumah dan Rumah Sakit, Puspa Swara, Jakarta.

[2] Graham, R.R., M. Juffrie, R. Tan, C.G. Hayes, I. Laksono, C. Ma'roef, E. Soetaryo, K.R. Porter, dan S.B. Halstead. 1999. A Prospective Seroepidemiologic Study on Dengue in Children Four to Nine Years of Age in Yogyakarta, Indonesia. Studies in 1995-1996. The American Society of Tropical Medicine and Hygiene, 6(3): 412 - 419.

[3] Candra, A., 2010, Demam Berdarah Dengue: Epidemiologi, Patogenesis, dan Faktor Risiko Penularan, Aspirator, 2(2):110 - 119.

[4] Khalid, M., Sultana, M., dan Khan, F.S., 2015, Numerical Solution of SIR Model of Dengue Fever, International Journal of Computer Applications, 118(21):1 - 4.

[5] Side, S. dan S.M. Noorani. 2013. A SIR Model for Spread of Dengue Fever Disease (Simulation for South Sulawesi, Indonesia and Selangor, Malaysia). World Journal of Modelling and Simulation, 9(2): 96 - 105.

[6] Weisstein, E.W. 2016. Kermack-McKendrik Disease Model.

http://mathworld.wolfram.com/Kermack-McKendrikModel.html, [26 Mei 2016].

[7] Nuraini, N., E. Soewono dan K.A. Sidarto. 2007. Mathematical Model of Dengue Disease Transmission with Severe DHF Compartment, Bulletin of the Malaysian Mathematical Sciences Society, 30(2): $43-157$.

[8] Khan, Q.J.A. dan D. Greenhalgh. 1998. Hopf Bifurcation in Epidemic Models with A Time Delay in Vaccination, Mathematical Medicine and Biology, 16(2):113 - 142.

[9] Martin, A. dan S. Ruan. 2001. Predator-prey Models with Delay and Prey Harvesting, Journal of Mathematical Biology, 43(3): 247 - 267.

[10] Xiao, Y. dan L. Chen. 2001. Modeling and Analysis of A Predator-Prey Model with Disease in the Prey, Mathematical Biosciences, 171(1): 59 - 82

[11] Patanarapelert, K.,dan L.M. Tang. 2007. Effect of Time Delay on the Transmission of Dengue Fever, World Academy of Science, Engineering and Technology, 10:395 - 403.

[12] Marsden, J.E. dan M. McCracken. 1976. The Hopf Bifurcation and Its Application, SpringerVerlag, New York. 
[13] Abta, A., H. Laarabi dan H.T. Alaoui. 2014. The Hopf Bifurcation Analysis and Optimal Control of Delayed SIR Epidemic Model, International Journal of Analysis, 2014: 1 - 10.

[14] Kumar, R.G., L.K. Narayan dan R.B. Reddy. 2016. Stability and Hopf Bifurcation Analysis of SIR Epidemic Model with Time Delay, ARPN Journal of Engineering and Applied Sciences, 11(3):1419 - 1423 . 